https://helda.helsinki.fi

\title{
When bats go viral : negative framings in virological research imperil bat conservation
}

\section{López-Baucells, Adrià}

2017-10-30

López-Baucells , A , Rocha , R \& Fernandez-Llamazares Onrubia , A 2017 , ' When bats go viral : negative framings in virological research imperil bat conservation ', Mammal Review , vol. 48 , no. 1 , pp. 62-66 . https://doi.org/10.1111/mam.12110

http://hdl.handle.net/10138/237764

https://doi.org/10.1111/mam.12110

unspecified

publishedVersion

Downloaded from Helda, University of Helsinki institutional repository.

This is an electronic reprint of the original article.

This reprint may differ from the original in pagination and typographic detail.

Please cite the original version. 


\title{
When bats go viral: negative framings in virological research imperil bat conservation
}

\author{
Adrià LÓPEZ-BAUCELLS* (iD) Centre for Ecology, Evolution and Environmental Changes, University of \\ Lisbon, C2 Building, 1749-016, Lisbon, Portugal and Museum of Natural Sciences of Granollers, \\ c/Palaudàries 102-Jardins Antoni Jonch Cuspinera, 08402, Granollers, Catalonia, Spain. \\ Email: adria.baucells@gmail.com \\ Ricardo ROCHA (D) Conservation Science Group, University of Cambridge, Downing St., CB23EJ, \\ Cambridge, UK and Metapopulation Research Centre, Department of Biosciences, University of \\ Helsinki, Viikinkaari 1, 00790, Helsinki, Finland. Email: ricardo.nature@gmail.com \\ Álvaro FERNÁNDEZ-LLAMAZARES (iD Metapopulation Research Centre, Department of \\ Biosciences, University of Helsinki, Viikinkaari 1, 00790, Helsinki, Finland. \\ Email: alvaro.fernandez-llamazares@helsinki.fi
}

\author{
Keywords \\ Chiroptera, ecosystem services, public health, \\ virology, virus \\ ${ }^{*}$ Correspondence author \\ Submitted: 13 July 2017 \\ Returned for revision: 18 August 2017 \\ Revision accepted: 5 September 2017 \\ Editor: DR
}

doi: $10.1111 /$ mam.12110

\begin{abstract}
The recent upsurge in bat-borne virus research has attracted substantial news coverage worldwide. A systematic review of virological literature revealed that bats were described as a major concern for public health in half of all studies (51\%), and that their key role in delivering ecosystem services was disregarded in almost all studies (96\%). Although research on zoonoses is of the utmost importance, biased framings of bats can undermine decades of conservation efforts. We urge researchers and science communicators to consider the conservation impacts of how research findings are presented to the public carefully, and, whenever possible, to highlight the ecological significance of bats, their dire conservation situation and their importance for human well-being.
\end{abstract}

\section{PRECONCEPTION}

Throughout history, bats have been victims of fear, hostility and cultural prejudice all over the world (Kingston 2016). These negative stigmas are being reinvigorated in the light of misinformed representations of bats in the media as a serious threat to human health (Schneeberger \& Voigt 2016). In an increasingly riskaverse society, media attention to zoonotic diseases has largely contributed to increasing animosity towards bats, often with unsupported evidence about disease transmission risks (Lunney \& Moon 2011). Although bats provide key ecosystem services, such as control of mosquitoes and agricultural arthropod pests, the media has often tended to offer a skewed vision of bats, presenting them only as dangerous reservoirs of deadly viruses. However, the scientific foundations on which these framings rely are still ill-researched.

\section{FRAMING ZOONOTIC DISEASE RISKS}

Framing involves the social construction of an issue, by providing meaning and conferring positive or negative values to it (Chong \& Druckman 2007). Scientists unavoidably employ frames to communicate research findings to wider audiences. By emphasising certain dimensions or giving greater weight to some considerations over others, researchers can use frames to influence social attitudes (Bertolotti \& Catellani 2014). In other words, framing a scientific topic in a particular way endows certain aspects of it with greater or lesser importance than they would have if the topic had been framed differently.

Experimental research has shown that frames can shape environmental risk perceptions strongly, and can thus compel or constrain societal action in the face of new social-ecological scenarios (Leiserowitz 2005). In the context of the current biodiversity crisis, effectively framing 
zoonotic disease risks in science communication remains of paramount importance for garnering social support for conservation (Buttke et al. 2015, Terraube et al. 2017). However, environmental attitudes are also contingent upon cultural forces that interact with externally crafted frames. Whether a specific scientific communication is taken up or not depends largely on its correspondence with the cultural values of the audience (Fernández-Llamazares et al. 2015).

Over the years, bats have developed a dark reputation worldwide, fed by legends, myths and folklore (Kingston 2016). Perceptions of bats have been galvanised in recent years by a prolific body of virological bat-related research (see Fig. 1), attracting widespread media attention and generating frightening headlines worldwide. Several bat conservation organisations have tried to mitigate the negative conservation impacts of this undesired media attention. A prominent example is the group "Communication, Bat Conservation and Public Health" within Eurobats (http:// www.eurobats.org/), which is making a concerted effort to increase literacy about emerging viral zoonoses among bat researchers, conservation practitioners and science communicators.

Based on a review of research articles containing the words "bats" and "virus" in the title, we examined how bat-related health risks are generally framed within science and the potential societal implications of such framings in the context of bat conservation.

\section{BATS, VIRUSES AND FRAMES}

Our review revealed that bats were framed as a major concern for public health in half of all virological studies (in $51 \%$ of all the papers reviewed), but that only scarce consideration was given to their key role in delivering ecosystem services on which human health depends (these were mentioned in only $4 \%$ of studies). This negative framing was found to lie on weak empirical footing (at least in the papers): evidence was not provided on the potential disease transmission pathways from bats to humans (in $62 \%$ of studies), the real proportion of infected bats $(70 \%)$, or the number of lethal cases in humans $(78 \%)$. Overall, information on the context of bat-associated infections, the real probability of spillover events and the conditions facilitating potential transmission was meagre at best, if not lacking (Fig. 2).

The language routinely employed included a repertoire of value-laden terms such as "attacked" (Steece \& Calisher 1989), "threat" (Wynne et al. 2014), and "fatal" (Regunath et al. 2016), and passages were loaded with negative connotations prone to misinterpretation. For instance, authors reported that "many zoonotic viruses that have emerged recently are thought to have their origins in bats" (Wang et al. 2015) and that "many emerging and re-emerging infectious diseases are zoonoses derived from wildlife, particularly bats" (Wynne et al. 2014). Although it has recently been found that bats host a significantly higher

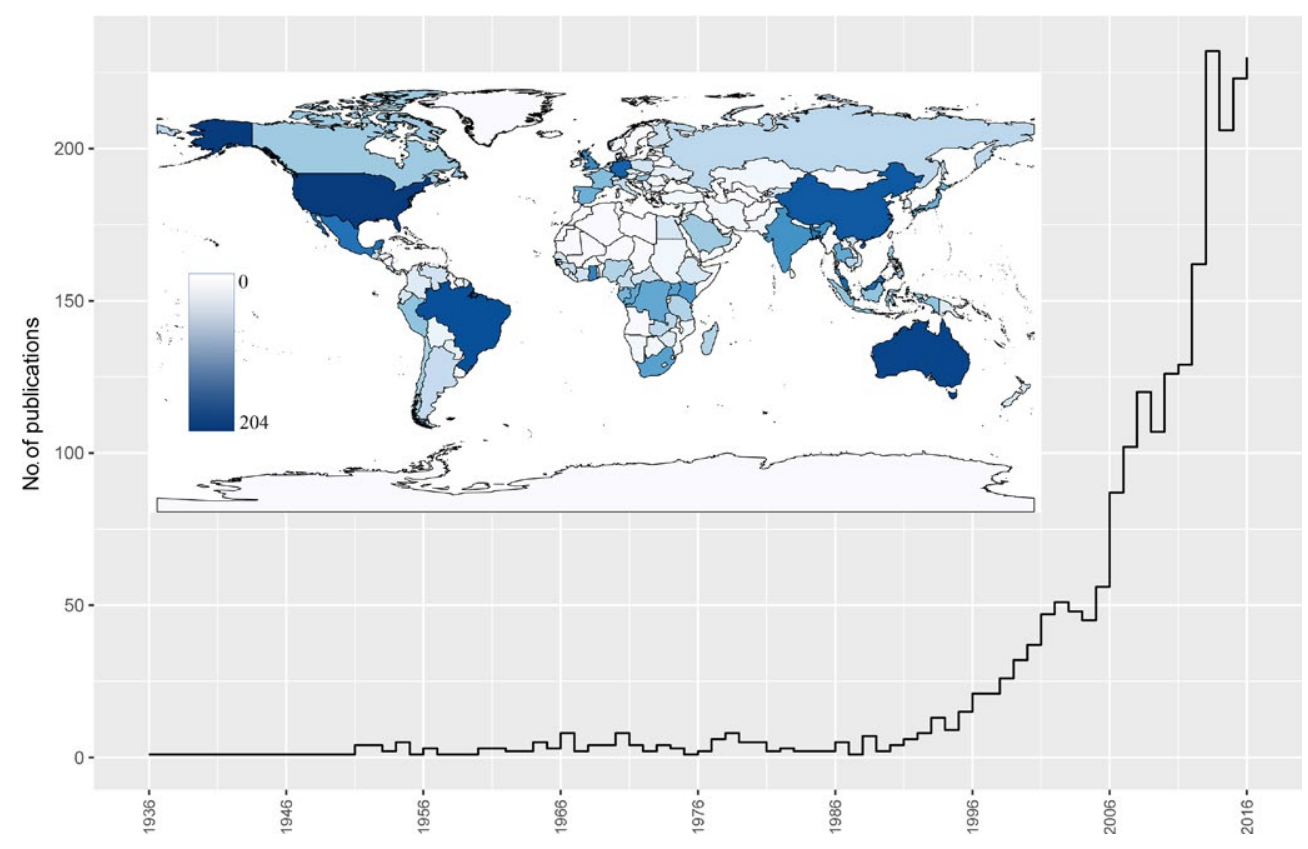

Fig. 1. Virological bat-related publication trend from 1936 to 2016. The number of publications was quantified both spatially and temporally through a systematic search in Web of Science for all papers containing the words "virus" and "bats" ( $N=2441$ papers). [Colour figure can be viewed at wileyonlinelibrary.com] 


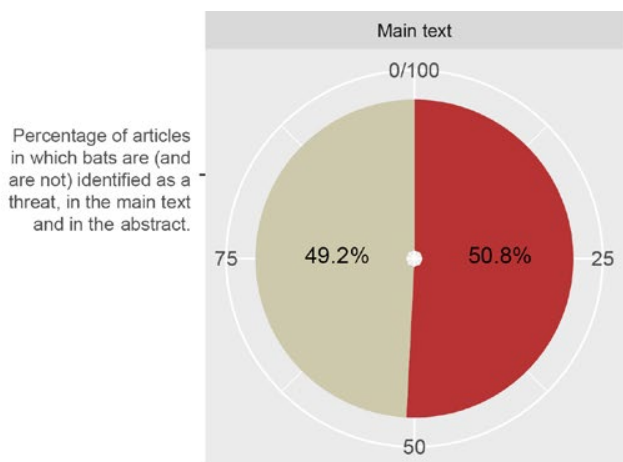

Does the paper provide information about...

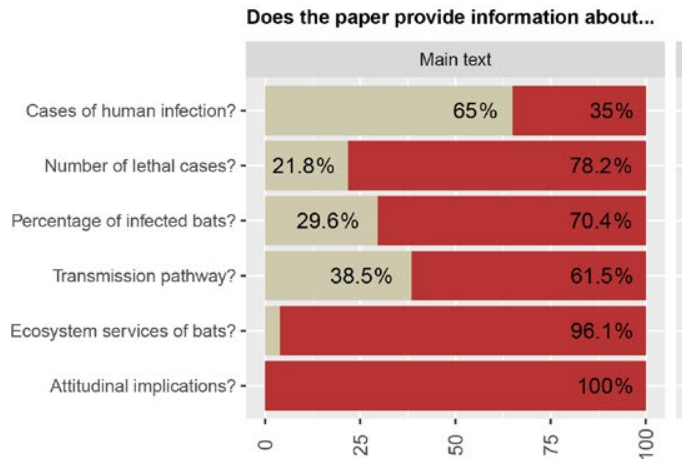

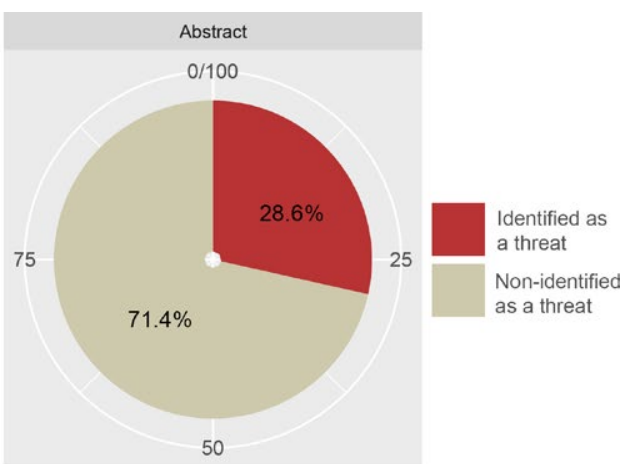

50

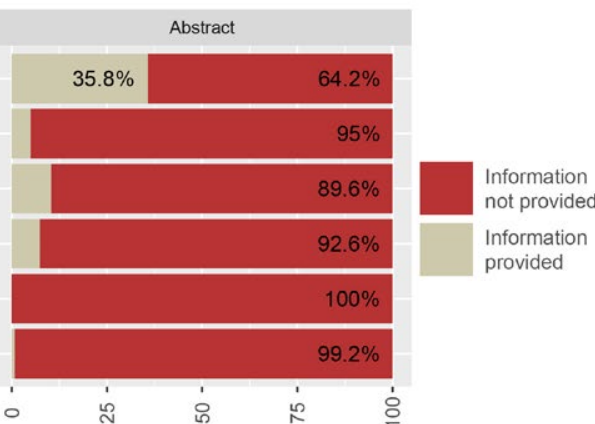

Fig. 2. Systematic review of all available scientific papers containing the words "bats" and "virus" in the title, obtained through a systematic search in Google Scholar $(N=135)$. In the pie charts, the slices show the percentage of papers (main text and Abstract) in which bats are and are not described as a threat to human health. In the bar charts, bars show the percentage of papers in which specific information about different aspects of bat-human interactions is and is not reported (as summarised by the questions on the left). [Colour figure can be viewed at wileyonlinelibrary.com]

proportion of zoonoses than other mammals (Olival et al. 2017), there are still only poor real-world data showing to which extent such diseases might jump from wildlife to humans (Kupferschmidt 2017). Moreover, direct associations of unrelated statements placed in proximity and missing critical information led to misleading conclusions. For example, authors asserted that "rabies virus is responsible for nearly all the 40.000-60.000 human deaths that occur on a global basis (...). Indeed, most human deaths in the USA are due to bat-associated rabies virus" (Davis et al. 2006), disregarding the fact that only 19 cases of bat-related rabies have been recorded in the USA since 2003 (https://www.cdc.gov/rabies/location/usa/surveillance/ human_rabies.html).

Although we acknowledge that bats may represent an important share of natural virus reservoirs (Anthony et al. 2017, Maxmen 2017, Olival et al. 2017) that might eventually pose danger to people, we remain firm in asserting that the risk of virus transmission from bats to humans is small (Kingston 2016, Anthony et al. 2017), an aspect that is worryingly neglected in most virological bat-related publications. Moreover, the fact that an increasing number of virus outbreaks is largely attributable to human encroachment in natural areas (Buttke et al. 2015, Terraube et al. 2017) is rarely publicised. In this context, more emphasis could be placed on the available measures to prevent spillover events, which tend to be relatively easy to implement (Dobson 2005) given that bat-human contacts are generally limited due to the elusive and nocturnal behaviour of bats.

Considering that the abstract is, apart from the title, the most frequently read and most easily accessed part of an article (Meijnders et al. 2001), we decided to compare the information provided in the abstract with that provided in the main text. If essential information on human-bat interactions was scant in the manuscript (not provided in $35-100 \%$ of papers), the situation became more acute in the abstracts (not provided in 64-100\%; Fig. 2). Uninformative, partial and decontextualised abstracts significantly contribute to spreading negative emotions such as fear or aversion towards bats, posing major obstacles to their long-term conservation.

\section{WHEN BATS GO VIRAL}

Biased framings of bats in the scientific literature have an enormous potential to permeate beyond scholarly circles. Bat-associated health risks have all the traits needed for them to be amplified through social media platforms, given the wide array of negative images that bats evoke 
in the general public. For example, a recent review on zoonotic patterns of viral diversity in wildlife (Olival et al. 2017) was covered in the media with headlines such as "Bats are special, but not in a good way" (Anonymous 2017a) and "Bats are the number-one carriers of disease" (Sifferlin 2017). By the same token, the death, diagnosed as being due to rabies, of one man in Brazil who stepped on a bat, triggered widespread media attention with articles such as "Vampire bats terrorise Brazilian city as one man dies of rabies" (Beresford 2017) and "Vampire bats attack, feast on humans in Brazil" (Anonymous 2017b). These cultural associations generate widespread social attention, often magnifying risk perceptions over actual levels of risk (Kingston 2016).

Some authors of virological bat-related papers have started to underscore the ecological roles of bats and at least mention some of the ecosystem services that bats provide ( $4 \%$ of papers). Yet, as noble as these aspirations might be, they are still falling short in improving the status of bats in the public eye if accompanied by powerful over-statements of loathing. While fear easily spreads from person to person, just like a virus, values such as respect or esteem for bats take long time to sediment. Endorsing bats requires intense educational efforts in order to transform culturally ingrained qualms into informed understanding of the contributions of bats to human wellbeing (Kingston 2016). Considering the fact that disgust for bats often results in deliberate culling of bat populations (Streicker et al. 2012), rethinking of how bats are framed in virological studies is urgently needed.

\section{CONSERVATION WITHOUT PREJUDICE}

Public support for bat conservation is strongly influenced by reports of zoonotic viral diseases that are fatal to humans. Indeed, emerging zoonotic viruses (bat-related or not) have often led to direct persecution of bats, extermination campaigns and destruction of bats' roosting sites. For example, the identification of flying foxes as a putative natural host for the Hendra virus in Australia resulted in large-scale killing and harassment of bats (Roberts et al. 2012). Similarly, caves in North America harbouring considerable bat colonies have been recurrently burned, primarily due to generated fear around rabies transmission (O’Shea et al. 2016).

Demonisation of bats by disease-related speculation is significantly eroding the values that society places on them, undermining decades of conservation efforts that were heading in the right direction. An integrated and interdisciplinary approach to articulating bat-related science communication is thus urgently called upon in order to provide society with a balanced, comprehensive and unbiased perception of bats. Reframing bat-related health risks is unquestionably of the essence, if bats are to persist in the Anthropocene.

\section{ACKNOWLEDGEMENTS}

We dedicate this paper to all the people who work tirelessly to conserve bats throughout the world. We thank Mar Cabeza, Carles Flaquer and Xavier Puig-Montserrat for all our insightful conversations on how to reframe bats in the public eye. ALB has been supported by Fundação para a Ciência e a Tecnologia (PD/BD/52597/2014), AFLl has been supported by the Academy of Finland (grant agreement nr. 311176) and the Kone Foundation, and RR has been supported by Fundação para a Ciência e a Tecnologia (PD/BD/52597/2014). We also thank the two anonymous reviewers that corrected previous versions of this manuscript.

\section{REFERENCES}

Anonymous (2017a) Bats are special. But not in a good way. Pri's The World. https:/www.pri.org/stories/2017-06-27/ bats-are-special-not-good-way

Anonymous (2017b) Vampire bats attack, feast on humans in Brazil. Vanguard. http://www.mirror.co.uk/news/worldnews/blood-sucking-vampire-bats-spark-10528747

Anthony SJ, Johnson CK, Greig DJ, Kramer S, Che X, Wells $\mathrm{H}$ et al. (2017) Global patterns in coronavirus diversity. Virus Evolution, 3, vex012.

Beresford M (2017) Vampire bats terrorise Brazilian city as one man dies of rabies. The Telegraph. http://www. telegraph.co.uk/news/2017/05/30/ vampire-bats-terrorise-brazilian-city-one-man-dies-rabies/

Bertolotti M, Catellani P (2014) Effects of message framing in policy communication on climate change. European Journal of Phycology 44: 474-486.

Buttke DE, Decker DJ, Wild MA (2015) The role of One Health in wildlife conservation: a challenge and opportunity. Journal of Wildlife Diseases 51: 1-8.

Chong D, Druckman JN (2007) Framing theory. Annual Review of Political Science 10: 103-126.

Davis PL, Bourhy H, Holmes EC (2006) The evolutionary history and dynamics of bat rabies virus. Infection, Genetics and Evolution : Journal of Molecular Epidemiology and Evolutionary Genetics in Infectious Diseases 6: 464-473.

Dobson AP (2005) What links bats to emerging infectious diseases? Science 310: 628-629.

Fernández-Llamazares Á, Méndez-López ME, Díaz-Reviriego I, McBride MF, Pyhälä A, Rosell-Melé A, Reyes-García V (2015) Links between media communication and local perceptions of climate change in an indigenous society. Climatic Change 131: 307-320. 
Kingston T (2016) Cute, creepy, or crispy - how values, attitudes, and norms shape human behavior toward bats. In: Voigt C, Kingston T (eds) Bats in the Anthropocene: Conservation of Bats in a Changing World, 571-595. Springer International Publishing, Berlin, Germany.

Kupferschmidt K (2017) Bats really do harbor more dangerous viruses than other species. Science. http://www. sciencemag.org/news/2017/06/

bats-really-do-harbor-more-dangerous-viruses-other-species

Leiserowitz AA (2005) American risk perceptions: is climate change dangerous? Risk Analysis 25: 1433-1442.

Lunney D, Moon C (2011) Traditional prejudices and today's bad press render bats invisible to public consciousness. In: Law B, Eby P, Lunney D, Lumsden L (eds) Biology and Conservation of Australasian Bats, 44-63. Royal Zoological Society of New South Wales, Mosman, Australia.

Maxmen A (2017) Bats are global reservoir for deadly coronaviruses. Nature 546: 340.

Meijnders AL, Midden CJ, Wilke HA (2001) Role of negative emotion in communication about $\mathrm{CO}_{2}$ risks. Risk Analysis 21: 955-955.

Olival KJ, Hosseini PR, Zambrana-Torrelio C, Ross N, Bogich TL, Daszak P (2017) Host and viral traits predict zoonotic spillover from mammals. Nature 546: 646-650.

O'Shea TJ, Cryan PM, Hayman DTS, Plowright RK, Streicker DG (2016) Multiple mortality events in bats: a global review. Mammal Review 46: 175-190.

Regunath H, Chinnakotla B, Rojas-Moreno C, Salzer W, Hughes NJ, Sangha H (2016) A case of fatal serotonin syndrome-like human rabies caused by tricolored bat-associated rabies virus. American Journal of Tropical Medicine and Hygiene 94: 1376-1379.
Roberts BJ, Catterall CP, Eby P, Kanowski J (2012) Latitudinal range shifts in Australian flying-foxes: a re-evaluation. Austral Ecology 37: 12-22.

Schneeberger K, Voigt CC (2016) Zoonotic viruses and conservation of bats. In: Voigt C, Kingston T (eds) Bats in the Anthropocene: Conservation of Bats in a Changing World, 263-292. Springer International Publishing, Berlin, Germany.

Sifferlin A (2017) Bats Are the Number-One Carriers of Disease. TIME. http://time.com/4827511/ bats-viruses-diseases-pandemic/

Steece RS, Calisher CH (1989) Evidence for prenatal transfer of rabies virus in the mexican free-tailed bat (Tadarida brasiliensis mexicana). Journal of Wildlife Diseases 25: 329-334.

Streicker DG, Altizer SM, Velasco-Villa A, Rupprecht CE (2012) Variable evolutionary routes to host establishment across repeated rabies virus host shifts among bats. Proceedings of the National Academy of Sciences of the United States of America 109: 19715-19720.

Terraube J, Fernández-Llamazares Á, Cabeza M (2017) The role of protected areas in supporting human health: a call to broaden the assessment of conservation outcomes. Current Opinion in Environmental Sustainability 25: 50-58.

Wang J, Moore NE, Murray ZL, McInnes K, White DJ, Tompkins DM, Hall RJ (2015) Discovery of novel virus sequences in an isolated and threatened bat species, the New Zealand lesser short-tailed bat (Mystacina tuberculata). Journal of General Virology 96: 2442-2452.

Wynne JW, Shiell BJ, Marsh GA, Boyd V, Harper JA, Heesom K et al. (2014) Proteomics informed by transcriptomics reveals Hendra virus sensitizes bat cells to TRAIL-mediated apoptosis. Genome Biology 15: 532. 